\section{Выращивание сосны кедровой сибирской в условиях Республики Карелия}

\author{
О. И. Гаврилова ${ }^{1}$ \\ Петрозаводский государственный университет
}

\begin{abstract}
АННОТАЦИЯ
Статья посвящена вопросам интродукции Pinus sibirica Mill. в условиях Республики Карелия. Приводятся сведения о росте культур сосны сибирской 23летнего возраста и естественном возобновлении в условиях бедных сухих почв.
\end{abstract}

Ключевые слова: сосна кедровая, интродукиия, лесные культуры, посадка, уходы.

\section{SUMMARY}

The article is devoted to questions connected with introduction of Pine Siberian in the Karelian Republic. The data on growth of 23-age Pine Siberian forest and natural reforestation in the condition of dry and poor soils are presented.

Keywords: Pine Siberian, introduction, forest culture, planting, tending.

\section{ВВЕДЕНИЕ}

Относительно бедный породный состав лесов Республики Карелия долгое время был объектом внимания лесоводов, имеется огромное количество предложений по его расширению [1]. Вопросы интродукции сосны кедровой обсуждаются уже на протяжении многих лет [2], и имеются рекомендации по созданию производственных лесных культур [3]. Довольно большое количество площадей в Карелии восстанавливалось сосной кедровой в 70-80-е годы прошлого столетия. Однако процесс восстановления лесов кедром весьма сложен и более своеобразен, чем у других хвойных пород.

Культуры кедра уместны на богатых суглинках и супесях с прослойками глины, где кедр прирастает в год по 30-40 см, развивая пышную крону. Желательным спутником кедра в зоне смешанных лесов является ель. Сосна обыкновенная быстро обгоняет кедр, затеняет его, вытесняя из состава насаждения. В целом при интродукции следует отдавать предпочтение чистым сплошным культурам, с густотой посадки 4-7 тыс. шт./га для сеянцев и 2,5-4 тыс. шт./га для саженцев. Перевод культур кедра в лесопокрытую площадь осуществляют в 8-10 лет, с последующим тщательным уходом за составом и полнотой в зависимости от целевого назначения культур.

Важным условием для акклиматизированного растения является сумма эффективных температур за период от «цветения» до созревания семян в новых

\footnotetext{
${ }^{1}$ Автор - дочент кафедры лесного хозяйства

( ) О. И. Гаврилова, 2003
}

условиях роста и развития. Эта величина может быть надёжным показателем, характеризующим, насколько сумма эффективных температур обеспечивает созревание семян сибирского кедра. Поскольку у сибирского кедра от «цветения» до созревания семян проходит два вегетационных периода, сумма эффективных температур подсчитывалась за два года. Так, от «Цветения» до созревания семян она составляла 1834 - $2235^{\circ} \mathrm{C}$. Эта сумма температур обеспечивает их созревание. Общая же сумма эффективных температур с весны и до созревания шишек и семян (за два вегетационных периода) составляет $2150-2557^{\circ} \mathrm{C}$.

Сибирский кедр предпочитает суглинистые и супесчаные, достаточно увлажнённые, но хорошо дренируемые плодородные почвы. Однако в пределах своего естественного ареала он встречается на самых разнообразных типах почв и рельефе местности. Сухие песчаные почвы для кедра нежелательны. Особенно отличаются хорошим ростом и обильным охвоением деревья, растущие на плодородных почвах, содержащих в своём составе известь. Такие деревья отличаются высокой производительностью.

Климатические условия в разных частях Карелии существенно различаются, что создает неодинаковые предпосылки для успешной интродукции растений в том или ином районе. Наиболее благоприятные условия складываются на юге республике, по мере продвижения на север они заметно ухудшаются. Наиболее отрицательными факторами являются: холодная и продолжительная весна, нередко с небольшим количеством осадков; низкие зимние температуры, чередующиеся с частыми оттепелями; близкое залегание грунтовых вод; поздние весенние и ранние осенние напочвенные заморозки; значительное количество осадков, приходящееся на август-сентябрь, когда вегетационный период у большинства растений уже заканчивается. Положительное влияние на ход вегетации интродуцентов оказывает долгий летний день, продолжающийся в июне-июле около 20 часов и вызывающий у растений почти круглосуточное протекание ассимиляционных процессов.

\section{ХАРАКТЕРИСТИКА ОБЪЕКТА \\ ИССЛЕДОВАНИЯ}

На территории выдела были заложены две пробные площади по $600 \mathrm{~m}^{2}$. На первой из них в момент исследования произрастали: сосна кедровая сибирская, ель европейская, сосна обыкновенная, береза и осина, в т. ч. 50 шт. сосны кедровой сибирской (или 833 шт./га). На второй пробной площади густота составляет 433 шт. сосны кедровой на 1 га. Тип почвы подзол иллювиально-железистый. В составе напочвенного покрова преобладают виды растительности, характерные для бедных боровых почв (табл. 1).

Лесные культуры заложены способом посадки вручную под меч Колесова трехлетних сеянцев сосны кедровой с подготовкой почвы ПДН-2. Тип леса до рубки - сосняк брусничный 3-го класса бонитета, 100-летнего возраста. После рубки сформировался вейниково-луговиковый тип вырубки, к настоящему 
времени сформировалась лесная среда. Напочвенный покров представлен в основном лесными видами, полог насаждения сомкнут.

Таблица 1

Состав напочвенного покрова

\begin{tabular}{|l|c|}
\hline \multicolumn{1}{|c|}{ Виды растительности } & $\begin{array}{c}\text { Проектив- } \\
\text { ное покры- } \\
\text { тие, \% }\end{array}$ \\
\hline $\begin{array}{l}\text { Плеуроциум Шребера - Pleurozium } \\
\text { Schreberi ( Brid) Mitt }\end{array}$ & 34,5 \\
\hline $\begin{array}{l}\text { Политрихум обыкновенный (ку- } \\
\text { кушкин лен) - Polytrichum } \\
\text { commune Hedw }\end{array}$ & 15,2 \\
\hline $\begin{array}{l}\text { Дикранум метловидный - } \\
\text { Dicranum scoparium Hedw }\end{array}$ & 22,2 \\
\hline Черника - Vaccinium myrtyllus L & 8 \\
\hline Брусника - Vaccinium vitis-idaea L & 24,2 \\
\hline $\begin{array}{l}\text { Вейник лесной - Calamagrostis } \\
\text { silvatica DC }\end{array}$ & 3 \\
\hline
\end{tabular}

\section{РЕЗУЛЬТАТЫ ИССЛЕДОВАНИЙ}

По данным проведенных исследований для сосны кедровой сибирской для двух проб нами были вычислены статистические показатели по основным таксационным признакам, которые представлены в табл. 2.

Из представленных сведений видно, что максимальные значения по высоте имеет сосна обыкновенная, местная порода, которая отличается быстрым ростом и светолюбием. Другая местная порода - ель - имеет несколько меньшие показатели по сравнению с сосной кедровой, однако следует помнить, что она медленно растет в первые годы жизни. Лиственные породы - береза и осина - также превосходят сосну кедровую по высоте. Измерение диаметров хвойных пород показало, что местные виды превосходят по диаметру сосну кедровую сибирскую спустя 20 лет после посадки. Точность исследований не превышает при этом $10 \%$, а достоверность среднего значения не более $45 \%$, т. е. исследования проведены с достаточной точностью, при довольно больших вариациях показателей.

После анализа табличного материала можно сказать о слабой конкурентной способности сосны кедровой по сравнению с местным видами, при отсутствии уходов за составом в первые 5-10 лет после посадки. По высоте и диаметру к 20 годам начинают преобладать местные виды естественного происхождения по сравнению с интродуцированными.

По средним значениям таксационных показателей составлена таблица 3 , представляющая характеристику древесной растительности до проведения рубок ухода и после.

Анализ представленных данных показал, что при проведении рубок ухода убирали погибшие деревья сосны кедровой, большое количество ели, березы и сосны обыкновенной. Ольху серую совсем убрали, а осина, очевидно, выросла уже после проведения ру- бок ухода и имеет, видимо, вегетативное происхождение.

Таблица 2

Основные таксационные показатели насаждения по породам

\begin{tabular}{|c|c|c|c|c|c|c|c|}
\hline $\begin{array}{c}\text { Основ- } \\
\text { ные так- } \\
\text { сацион- } \\
\text { ные пока- } \\
\text { затели }\end{array}$ & \begin{tabular}{|c} 
Сред- \\
нее \\
значе- \\
ние
\end{tabular} & $\begin{array}{l}\text { Дис- } \\
\text { пер- } \\
\text { сия }\end{array}$ & $\begin{array}{l}\text { Сред- } \\
\text { нее } \\
\text { откло- } \\
\text { кло- } \\
\text { нение }\end{array}$ & $\begin{array}{l}\text { Оши } \\
\text { бка } \\
\text { сред } \\
\text { него }\end{array}$ & \begin{tabular}{|l|} 
Коэф- \\
фици- \\
ент \\
измен \\
мен- \\
чиво- \\
сти, \%
\end{tabular} & $\begin{array}{c}\text { Точ- } \\
\text { ность } \\
\text { иссле- } \\
\text { сле- } \\
\text { дова- } \\
\text { ний, } \\
\%\end{array}$ & $\begin{array}{l}\text { Дос- } \\
\text { то- } \\
\text { вер- } \\
\text { ность } \\
\text { сред- } \\
\text { него }\end{array}$ \\
\hline \multicolumn{8}{|c|}{ Проба 1} \\
\hline \multicolumn{8}{|c|}{ Сосна кедровая сибирская } \\
\hline Высота, м & 3,8 & 3,2 & 1,4 & 0,2 & 38 & 5,4 & 18,6 \\
\hline $\begin{array}{l}\text { Диаметр, } \\
\text { см }\end{array}$ & 4,4 & 8,1 & 2,4 & 0,3 & 54,9 & 7,8 & 12,9 \\
\hline $\begin{array}{l}\text { Прирост, } \\
\text { см }\end{array}$ & 11,4 & 94,7 & 8,2 & 1,2 & 72,1 & 10,2 & 9,8 \\
\hline \multicolumn{8}{|c|}{ Ель европейская } \\
\hline Высота, м & 3,5 & 11,3 & 2,2 & 0,2 & 62,2 & 5,6 & 17,9 \\
\hline $\begin{array}{l}\text { Диаметр, } \\
\text { см }\end{array}$ & 8,9 & 36,4 & 4,3 & 0,4 & 49 & 4,2 & 23,8 \\
\hline \multicolumn{8}{|c|}{ Сосна обыкновенная } \\
\hline Высота, м & 5,4 & 10,5 & 2,3 & 0,4 & 42,3 & 6,9 & 14,5 \\
\hline $\begin{array}{l}\text { Диаметр, } \\
\text { см }\end{array}$ & 8,3 & 16,8 & 3,1 & 0,5 & 37,6 & 6,5 & 15,5 \\
\hline \multicolumn{8}{|c|}{ Береза } \\
\hline Высота, м & 4,1 & 0,8 & 0,5 & 0,1 & 13 & 2,7 & 37,7 \\
\hline \multicolumn{8}{|c|}{ Осина } \\
\hline Высота, м & 3,8 & 1,1 & 0,8 & 0,3 & 20,8 & 6,9 & 14,4 \\
\hline \multicolumn{8}{|c|}{ Проба 2} \\
\hline \multicolumn{8}{|c|}{ Сосна кедровая сибирская } \\
\hline Высота, м & 5,2 & 1,9 & 1,1 & 0,2 & 20,8 & 4,1 & 24,5 \\
\hline $\begin{array}{l}\text { Диаметр, } \\
\text { см }\end{array}$ & 6,3 & 6,3 & 1,9 & 0,4 & 30,3 & 5,9 & 16,9 \\
\hline $\begin{array}{l}\text { Прирост, } \\
\text { см }\end{array}$ & 21,4 & 17,7 & 3,7 & 0,9 & 17,3 & 4 & 25,2 \\
\hline \multicolumn{8}{|c|}{ Ель европейская } \\
\hline Высота, м & 4,2 & 3,8 & \begin{tabular}{|l|}
1,5 \\
\end{tabular} & 0,1 & 35,1 & 3,1 & 32 \\
\hline $\begin{array}{l}\text { Диаметр, } \\
\text { см } \\
\end{array}$ & 6,2 & 2,3 & 1,2 & 0,1 & 19,8 & 2,4 & 41,3 \\
\hline \multicolumn{8}{|c|}{ Береза } \\
\hline Высота, м & 5,6 & 1,5 & 0,9 & 0,1 & 16,5 & 2,6 & 38,7 \\
\hline $\begin{array}{l}\text { Диаметр, } \\
\text { см }\end{array}$ & 5,9 & 4,1 & 1,4 & 0,3 & 24,3 & 4,7 & 21,4 \\
\hline \multicolumn{8}{|c|}{ Сосна обыкновенная } \\
\hline Высота, м & 5,8 & 8,7 & 2,5 & 0,6 & 43,1 & 10,5 & 9,6 \\
\hline $\begin{array}{l}\text { Диаметр, } \\
\text { см }\end{array}$ & 9,7 & 8,8 & 2,2 & 0,6 & 22,4 & 6,5 & 15,5 \\
\hline
\end{tabular}

При проведении ухода вырубались засохшие деревья сосны кедровой больших диаметра и высоты, т. к. эти показатели уменьшились. Кроме того, произошло уменьшение и показателей естественно возобновившихся пород, что понятно, т. к. вырубались превосходяшие по высоте и затеняющие сосну кедровую экземпляры. Следует особо отметить неудовлетвори- 
тельное состояние деревьев сосны кедровой в связи с большой поврежденностью шютте обыкновенным (около 75\% деревьев имели пожелтевшую хвою на нижней трети кроны с признаками болезни).

Таблица 3

Характеристика древесной растительности в культурах сосны кедровой сибирской

\begin{tabular}{|l|c|c|c|c|c|c|}
\hline \multicolumn{6}{|c|}{ Характеристика древесной растительности } \\
\hline Порода & $\begin{array}{c}\text { До проведения } \\
\text { рубок ухода }\end{array}$ & \multicolumn{3}{|c|}{$\begin{array}{c}\text { После проведения } \\
\text { рубок ухода }\end{array}$} \\
\cline { 2 - 8 } & \multicolumn{2}{|c|}{1998 год } & \multicolumn{3}{c|}{2001 год } \\
\cline { 2 - 8 } & $\begin{array}{c}\text { Гу- } \\
\text { стота, } \\
\text { шт./га }\end{array}$ & $\begin{array}{c}\text { м, } \\
\text { см }\end{array}$ & $\begin{array}{c}\text { Гу- } \\
\text { стота, } \\
\text { шт./га }\end{array}$ & $\begin{array}{c}\text { м, } \\
\text { м }\end{array}$ & $\begin{array}{c}\text { Д, } \\
\text { см }\end{array}$ & \\
\hline $\begin{array}{l}\text { Сосна кедро- } \\
\text { вая } \\
\text { сибирская }\end{array}$ & 900 & 5 & 4,7 & 833 & 3,8 & 4,4 \\
\hline $\begin{array}{l}\text { Ель европей- } \\
\text { ская }\end{array}$ & 2833 & 4,2 & 3,3 & 2067 & 3,5 & 8,9 \\
\hline Берёза & 1533 & 6 & 2,5 & 400 & 4,1 & \\
\hline $\begin{array}{l}\text { Сосна обык- } \\
\text { новенная }\end{array}$ & 817 & 6,4 & 5,2 & 633 & 5,4 & 8,3 \\
\hline Осина & 100 & 6,3 & 1,7 & 150 & 3,8 & - \\
\hline Ольха & 50 & 11 & 5 & - & - & - \\
\hline
\end{tabular}

На основании полученных данных по характеристике древесной растительности была изучена динамика распределения пород по густоте, по высоте и по диаметру до рубок ухода и после. Наибольшая густота в культурах сосны кедровой сибирской до рубок ухода была у ели европейской (2833 шт./га), а наименьшая у сосны кедровой (900 шт./га). Таким образом, сосна кедровая сибирская находилась под сильным воздействием ели европейской и даже после проведения рубок ухода густота ели почти в 2,5 раза превышала культуры сосны кедровой.

До рубок ухода у сосны кедровой наблюдалась почти самая маленькая высота -5 м, следовательно, сосна находилась в сильном затенении. В результате рубок ухода был вырублен сухостой кедра довольно крупного размера, поэтому высота в среднем достигла только 3,8 м. Диаметр до рубок ухода у сосны кедровой не намного отличался от произрастающих здесь деревьев, но после рубок ухода у ели европейской и у сосны обыкновенной диаметр увеличился почти в 2 раза.

По сравнению с 1998 годом средняя высота сосны кедровой уменьшилась на $24 \%$, а диаметр - на $6 \%$, что говорит об удалении крупномерных, но погибших экземпляров сосны кедровой. Средняя высота ели уменьшилась на $17 \%$, однако при этом произошло увеличение диаметра почти в три раза, что может быть следствием проведения рубок ухода с удалением подроста. Средняя высота березы уменьшилась после удаления затеняющих сосну кедровую деревьев. Даже после рубок ухода культуры сосны кедровой находятся в худшем состоянии по сравнению с елью европейской и сосной обыкновенной.

\section{ВЫВОДЫ}

После проведения анализа роста и развития лесных культур - сосны кедровой сибирской - на территории Пряжинского лесхоза были сделаны следующие выводы.

Сосну кедровую сибирскую для интродукции в условиях Карелии можно рекомендовать для озеленительных работ, формирования мест отдыха и для ландшафтного проектирования вблизи населенных пунктов. Для производственной интродукции по результатам исследования рекомендовать ее нельзя. Причиной этого является сложность в подборе площадей, отвечающих особым требованиям этой породы, необходимость проведения своевременных уходов и отсутствие устойчивого спроса на древесину сосны кедровой.

Сосна кедровая сибирская 23-летнего возраста находится в неудовлетворительном состоянии. Состав насаждения до проведения рубок ухода можно представить как 1Скедр 5Е 1Соб 3Б, ед. Ос, Ол. После проведения в 23-летнем возрасте рубок ухода сформировали насаждение с составом: 2Скедр 5Е 2Соб 1Б, ед. Ос, Ол. Причиной этого служат поздно проведенные рубки ухода. Кроме того, преобладание по высоте было за березой и сосной обыкновенной. При интродукции для сосны кедровой сибирской предпочтительны чистые сплошные культуры либо смешанные с елью, так как сосна обыкновенная быстро обгоняет в росте кедр. Преобладание сосны кедровой сибирской по высоте и составу можно обеспечить только своевременным проведением рубок ухода.

Следовательно, при соблюдении правильности подбора площадей под лесные культуры со своевременными рубками ухода сосна кедровая сибирская неплохо будет себя чувствовать в условиях Карелии. Для создания лесных культур - сосны кедровой сибирской - на относительно богатых типах почвы лучше использовать посадку и формировать состав древостоя в течение первых 5-10 лет роста. Проведение их в более поздние сроки не обеспечит преобладания сосны кедровой по высоте и составу.

\section{СПИСОК ЛИТЕРАТУРЫ}

1. Андреев К. А. Интродукция деревьев и кустарников в Карелии. Петрозаводск, 1977. 144 с.

2. Валяев В. Н. К вопросу об интродукции хвойных в условиях Карелии // Развитие науки в Карелии за 50 лет советской власти. Петрозаводск, 1970. C. 126-129.

3. Руководство по лесовосстановлению в Гослесфонде Республики Карелия. Петрозаводск, 1995. $85 \mathrm{c}$. 